cost the shift would be negated. ${ }^{45}$ In the latter instance under the present law, the entire risk is theoretically borne by the sub-third party. In actuality, however, this risk is shifted to the prime. If the law were changed, part of this risk would be shifted to the sub-employer. But, since the sub-employer would in turn shift this risk to the prime, the situation would be substantially the same as if the law had not been changed.

In many of the other cases where a change in the law would be reflected in a change in risk distribution, it would appear that this result is of questionable desirability. These cases involve a public utility in the role of the third party, ${ }^{46}$ and due to the relatively inelastic demand curve of public utilities they are usually in a better position than non-utility employers to pass on the insurance cost to the general public.

It appears that not only would employees tend to be harmed by a significant change, but such a change would often fail to achieve the desired result of shifting the risk. Thus it would seem unwise to change the present law.

${ }^{45}$ In the construction business the prime contractor includes his insurance cost in the bid he submits to the owner. If the law were changed, the prime's insurance costs would be reduced in proportion to his reduced risk. On the other hand, the insurance costs of the sub-contractor will be raised proportionately. Since the increased insurance cost would affect all sub-contractors in the same field, e.g., plumbers, the sub-contractors would be able to increase their bids to the primes without affecting their competitive position. The prime will be willing to contract for the same quantity of business at the increased bids since the increase will merely offset the decrease in insurance premiums applicable to sub-contracts. And since the ultimate bid to the owner would not be affected by the change, the industry's demand curve would likewise not ultimately be affected. It is possible, however, that after the risk is shifted to the sub via the change in the law, and before the subs include the cost of the risk in their bids, the prime will lower his prices and thereby theoretically increase the demand for his services. To meet the increased demand, the prime's need for the services of the subs will be increased. This should cause the price of the sub's services to increase. Thus, even before the subs include the cost of the risk shifted to them via the change in the law in their bids to the primes, the risk in effect will be shifted back to the prime.

${ }^{46}$ E.g., United Gas Corp. v. Guillory, 206 F.2d 49 (C.A. 5th, 1953) (explosion of natural gas injured the plaintiff-construction worker); Shreveport v. Southwestern Gas \& Electric Co., 145 La. 680, 82 So. 785 (1919) (fireman killed by coming into contact with high tension wire); Fidelity \& Casualty v. Cedar Valley Electric Co., 187 Iowa 1014, 174 N.W. 709 (1919) (telephone employee came into contact with improperly installed high tension wire).

\title{
THE HEARSAY EXCEPTION FOR CO-CONSPIRATORS' DECLARATIONS
}

The conspiracy charge, long established ${ }^{1}$ as an important weapon of prosecution, ${ }^{2}$ has lately been subject to severe judicial and scholarly criticism. ${ }^{3}$

1 See The Conspiracy Dilemma: Prosecution of Group Crimes or Protection of Individual Defendants, 62 Harv. L. Rev. 276, 277 n. 5(1948).

2 O'Dougherty, Prosecution and Defense Under Conspiracy Indictments, 9 Brooklyn L. Rev. 263 (1940).

${ }^{3}$ See Krulewitch v. United States, 336 U.S. 440, 445-58 (1949) (Jackson, J., concurring); Grunewald v. United States, 353 U.S. 391, 404-5 (1957); Michael and Wechsler, Criminal Law and Its Administration 673-77, 686 (1940); The Conspiracy Dilemma: Prosecution of Group Crime or Protection of Individual Defendants, 62 Hary. L. Rev. 276, 277 n. 8 (1948). 
However, there has been little discussion of the rule of evidence which plays so large a part in the effectiveness of the charge-the co-conspirators' hearsay exception. ${ }^{4}$ Under this rule, one conspirator's declarations in furtherance of the conspiracy ${ }^{5}$ are admissible against his co-conspirators. These declarations are said to qualify as vicarious admissions $;{ }^{6}$ admissibility is predicated on the ground that concepts of vicarious responsibility which render conspirators criminally liable for each other's acts in furtherance also entail an evidential responsibility for statements in furtherance. ${ }^{7}$ But the pertinence of concepts of substantive vicarious responsibility to issues of admissibility has been peruasively challenged. ${ }^{8}$ The problem is further complicated by the fact that the admissions exception itself is difficult to harmonize with the basic rationale of hearsay exceptions. Accordingly, the basis for reception of admissions forms a useful point of departure for evaluation of the co-conspirators' exception.

\section{ADMISSIONS}

It has often been said that reception of admissions cannot always be justified on the basis of necessity or reliability. ${ }^{\circ}$ Accordingly, it has been urged

4 The most complete treatment found of the co-conspirators' exception is in Levie, Hearsay and Conspiracy, 52 Mich. L. Rev. 1159 (1954). See also Morgan, The Rationale of Vicarious Admissions, 42 Harv. L. Rev. 461, 464-66 (1929).

5 While the "furtherance" requirement is theoretically necessary to insure that the declaration be within the scope of the defendant's "authorization" implied from his participation in the conspiracy, there is some doubt as to whether courts give more than lip service to the requirement. Morgan, writing in 1929, stated that "often [the furtherance] requirement is verbally recognized, and the discussion is devoted to the time of the statement. But in numerous instances the report makes it clear that the words could not possibly have been uttered to further the common design.... It is, therefore, impossible to make a generalization from the existing decision, except to say that the law is in a state of flux, and seems to be tending to a rule that any statement of a conspirator concerning the conspiracy made while the conspiracy is subsisting is receivable against his co-conspirators." Morgan, op. cit. supra note 4, at 465. See Levie, op. cit. supra note 4, at 1167-72; McCormick, Evidence 522-23 (1954). The Uniform Rules and the Model Code abandon the furtherance requirement. Uniform Rules of Evidence, Rule 63 (9)(b); Mrodel Code of Evidence, Rule 508 (b). But cf. Krulewitch v. United States, 336 U.S. 440 (1949).

6 The commentators all discuss the co-conspirators' exception as a part of their discussion of vicarious admissions. 4 Wigmore, Evidence $\$ 1079$ (3d ed., 1940); McCormick, Evidence 521-23 (1954); Morgan, op. cit. supra note 4, at 464-66.

${ }^{7}$ Wigmore, loc. cit. supra note 6; Van Riper v. United States, 13 F.2d 961, 967(C.A.2d, 1926) (L. Hand, J.)

The co-conspirators' exception was once explained by a notion of res gestae: "as a declaration accompanying an act strongly indicates the nature and intention of the act or, more properly, perhaps, is to be considered as part of the act, a declaration made by one conspirator at the time of doing an act in furtherance of the common design is evidence against the other conspirators." 2 Starkie, Law of Evidence 403 (1824). Accord: Underhill, Law of Evidence $\$ 69$ (1894).

8 Morgan, op. cit. supra note 4.

9 Morgan, Admissions, 12 Wash. L. Rev. 181(1937); Chafee, Review of Wigmore on Evidence, 37 Harv. L. Rev. 513, 519 (1924). Contra: 4 Wigmore, Evidence $\$ 1048$ (3d ed., 1940). 
that the basis for admissions is an "estoppel,"10 or the "adversary theory of litigation." 11 But the analogy to estoppel is plainly question-begging. Estoppel usually operates to prohibit a party from denying prior inconsistent statements, not merely to bar his objection to their admission in evidence. ${ }^{12}$ Moreover, the function of estoppel is to protect persons who have reasonably relied on a party's prior inconsistent statements or conduct, ${ }^{13}$ which are then admitted for their operative effect on legal relations rather than as testimony. ${ }^{14}$ The "estoppel" label may reflect a feeling that, if truthful, the admissions should be received; if untruthful, that their use against the admitter "serves him right."15 But whether there should be a penalty for extra-judicial lying, and why it should take this capricious form, is not clear, and in any event this feeling seems to be irrelevant to cases of vicarious admissions. The "adversary theory" also explains nothing. To view the trial as a game may require that a party's mistakes made during litigation impair his chances of winning. Thus the party suffers for choosing incompetent counsel, failing to find evidence or to make proper objections. But it is not apparent that this approach should cover what was done before the "game" began.

The terms "estoppel" and "adversary theory" may represent vague sentiments behind the admissions exception. But it would seem that rational discussion must proceed in terms of considerations of reliability and necessity which, if not separately representing complete explanations of the admissions exception, may when taken together justify reception of admissions in most cases.

Originally the admissions exception might have been justified on the basis of a necessity arising from the incompetence of party witnesses. ${ }^{16}$ This justification still obtains to some extent: the party may still be incompetent or claim a privilege, and in cases where he does testify, the danger of bias may be such that his uncross-examined out-of-court statement, unless also made with a motive to misstate, could be considered preferable. However, it is difficult to argue that necessity for more reliable evidence justifies reception

${ }^{10} \mathrm{Lev}$, Law of Vicarious Admissions: An Estoppel, 26 U. of Cin. L. Rev. 17(1957); Gifford, Review of Wigmore on Evidence, 24 Col. L. Rev. 440, 443-44(1924), quoting with approval from Truby v. Seybert, $12 \mathrm{~Pa}$. St. 101, 104 (1849): "A man's acts, conduct and declarations wherever made are admissible against him, as it is fair to presume they correspond with the truth; and it is lis fault if they do not." (Italics added.)

11 Morgan, op. cit. supra note 9, at 182; Chafee, loc. cit. supra note 9.

12 Ewart, Estoppel by Misrepresentation 3-5 (1900). The estoppel analogy is more properly applied to judicial admissions, or to Greenleaf's theory that admissions are a "substitute for proof." See Morgan, Admissions as an Exception to the Hearsay Rule, 30 Yale I. J. 355-56(1921).

13 Ewart, note 12 supra, at cc. XI, XIII.

14 Pomeroy, Equity Jurisprudence $\S 801$ (5th ed., Symons, 1941); Bigelow, Estoppel 3-7 (6th ed., Carter, 1913).

${ }^{15}$ See Gifford, loc. cit. supra note 10.

I6 2 Wigmore, Evidence \$575-77, 579(3d ed., 1940). 
of admissions where the admitter had no personal knowledge of the subject matter of his statement, though in such cases admissions are generally received. ${ }^{17}$ Moreover, in many cases evidence as to the subject matter of the admission may be available from other sources, so that necessity could not be a compelling rationale unless the party's opportunity for knowledge was particularly advantageous.

Wigmore's justification for admissions was that cross-examination could in effect be obtained by the party "cross-examining himself"-taking the stand and explaining his statements. ${ }^{18}$ As an historical explanation this fails: until the middle of the last century parties were incompetent to testify..$^{19}$ Moreover, admissions may still be received today even though the admitter is unavailable, incompetent, or claims a privilege. ${ }^{20}$ In these situations, however, the ability-to-explain rationale retains some validity. To the extent that the explanation for the statement lies in events observed by the witness reporting the admission, or by any other available witness, the admitter's attorney may discover the facts from his client and thus guide his examination of witnesses so as to elicit an explanation of the admission. ${ }^{21}$

Finally, the fact that admissions are used against the admitter indicates that in a great many cases they were probably against interest when made and would qualify as declarations against interest were it not for the overlystrict limitations on that doctrine. ${ }^{22}$

\section{VICARIOUS ADMISSIONS}

Courts generally admit vicarious admissions on the ground that a principal's substantive responsibility for his agent's acts entails an evidential responsibility for his agent's statements. ${ }^{23}$ Professor Morgan has persuasively argued that this line of reasoning is fallacious, since vicarious substantive responsibility is based on social policies unrelated to the reliability and ne-

17 MICCormick, Evidence 505-7 (1954); Morgan, op. cit. supra note 9, at 182-83.

184 Wigmore, Evidence $\$ 1048$ (3d ed., 1940).

${ }^{19}$ See Gifford, op. cit. supra note 10, at 442, characterizing Wigmore's theory of admissions as an "ex post facto explanation."

${ }^{20}$ Morgan, op. cit. supra note 9, at 182 . Wigmore's assumption that ability to explain is a sufficient predicate of admissibility is drawn into question by cases excluding hearsay declarations by third parties subject to process or in court. Grand Forks Building \& Development Co. v. Implement Dealers Mutual Fire Ins. Co., 75 N.D. 618, 31 N.W.2d 495 (1948).

${ }^{21}$ See MIorgan, Admissions as an Exception to the Hearsay Rule, 30 Yale L. J. 355, 361 (1921). This rationale, of course, would not apply where the admitter is, at the time of trial, mentally incompetent, dead, or otherwise unable to advise his attorney. Yet in such cases the admission comes in. See Morgan, Admissions, 12 Wash. L. Rev. 181, 182 (1937).

${ }^{22}$ The requirements that the declaration be against proprietary rather than penal interest and the declarant dead are clearly unjustified; it has also been persuasively argued that there should be no requirement of unavailability. See Jefferson, Declarations Against Interest: An Exception to the Hearsay Rule, 58 Harv. L. Rev. 1, 6-8 (1944).

${ }^{23} 4$ Wigmore, Evidence $\$ 1079$ (3d ed., 1940). 
cessity of evidence. ${ }^{24}$ However, reliability and necessity are not the only justifications for rules of evidence, as the admissions exception itself seems to illustrate. It may be that the social policies behind respondeat superior might validly be implemented by rules of evidence as well as by rules of substantive law.

One policy behind respondeat superior is to prevent businessmen who act through agents from avoiding liability which would be imposed on single traders. ${ }^{25}$ To the extent that use of the alleged tortfeasor's admissions increases the chances of recovery, this substantive policy is implemented by reception of admissions against principals as well as against admitters. This practice does not err in the other direction by imposing an evidential penalty on acting through agents; in a few cases the vicarious admission forms the basis for an inference that the principal in fact made an admission, and in many other cases the vicarious admission itself is as necessary and reliable as most admissions.

In the former situation the principal's conduct betrays a belief in the truth of his agent's statement and thus may be viewed as an express or adoptive admission. ${ }^{26}$ Thus statements of an attorney in court or a witness on direct examination may be properly imputable to the client in subsequent litigation: if the statements had any importance in the case, they presumably were made with his approval, which could be taken as an indication that he believed them to be true. ${ }^{27}$

Necessity for vicarious admissions arises from the danger that the agent's statements in court may be biased in his own or his employer's favor. ${ }^{28}$ This rationale is persuasive only where no other available witness is as conversant with the facts as the agent. ${ }^{29}$ Furthermore, if the agent is no longer an em-

${ }^{24}$ Morgan, The Rationale of Vicarious Admissions, 42 Harv. X. Rev. 461 (1929).

${ }^{25}$ See Steffen, The Employer's "Indemnity" Action, supra, at 465; Laski, The Basis of Vicarious Liability, 26 Yale L. J. 105, 122-23 (1916).

${ }^{26}$ See Strahorn, The Hearsay Rule and Admissions, 85 U. of Pa. L. Rev. 564, 570 (1937); Morgan, Admissions, 1 U.C.L.A. L. Rev. 18, 20-25 (1953). Cf. Model Code of Evidence, Rule 507.

${ }^{27}$ See Morgan, op. cit. supra note 26, at 19. Where authorization is inferred from the statement itself, a "bootstrap" problem arises: a declaration is used as evidence of its own admissibility. The problem may be avoided in two ways. First, the hearsay rule might be held not to apply to bench hearings on questions of fact relating to admissibility. See Maguire and Epstein, Rules of Evidence in Preliminary Controversies as to Admissibility, 36 Yale L. J. 1101 (1927); McCormick, Evidence 123 n. 8 (1954). In addition, under one view of the hearsay rule the statement is non-hearsay in the voir dire since it is admissible as conduct tending to show the attorney's belief as to authorization, rather than as an explicit assertion. Cf. cases on spontaneous declarations, cited in McCormick, loc. cit. supra.

${ }^{28}$ See Model Code of Evidence, Rule 508, Comment (b). Compare the necessity said to justify the state of mind exception. 5 Wigmore, Evidence \$1714 (3d ed., 1940).

${ }^{29}$ Since an agent with authority to act concerning the subject matter of the admission is likely to be conversant with the facts, it has been argued that authority to act, rather than authority to speak, should be the test of admissibility for vicarious admissions. McCormick, Evidence 519 (1954). 
ployee at the time of trial, this rationale perhaps would not apply, since some of the reasons for his bias may have been eliminated. But admissibility might still be justified on the ground that an employer should not be able to exclude evidence by dismissing his employee. ${ }^{30}$

"Ability-to-explain" as a rationale of admissions might carry over in a modified form to some vicarious admissions cases. Under the requirement that the admission be made by an agent with authority to speak about its subject matter, ${ }^{31}$ courts have upheld reception against the employer of statements by interviewers, negotiators, investigators, and claim agents. ${ }^{32}$ In most of these cases the authority was probably accompanied by instructions as to what to say in given situations. If the employer can obtain testimony of the particular situation confronting his employee, he might be able to plausibly explain away the harmful implications of his agent's statements. ${ }^{33}$

Finally, the vast majority of vicarious admissions would probably qualify as declarations against interest, ${ }^{34}$ were it not for the illogical limitations of that doctrine. ${ }^{35}$ Where it can be foreseen that the statement might lead to the imposition of liability on the employer, the agent might be dismissed for having made such a statement. In addition, if the possible liability is in respondeat superior for the declarant's tort, the declaration may lead to dismissal by convincing the employer that the agent had been careless, and may subject the agent to liability to the injured person or to the employer in an action over. ${ }^{36}$

\section{CO-CONSPIRATORS' DECLARATIONS IN FURTHERANCE}

The general formula is that the declarations of one conspirator during the course of the conspiracy and in furtherance of its objectives are admissible

\footnotetext{
${ }^{30}$ Moreover, the bias may be present even though the declarant is no longer an employee of the party at the time of trial. Compare cases holding that statutes permitting examination of a party's employee as an adverse witness require only that the witness have been an employee at the time of the transaction to which he testifies. Scott v. Del Monte Properties, 140 Cal. App. 2d 756, 295 P.2d 947 (1956); cases collected in Who is "Employee" within Statutes Permitting Examination, as Adverse Witness, of Employee of Party, 56 A.L.R. 2d 1108 (1957).

31 McCormick, Evidence 517-18 (1954).

32 Moran v. Pittsburgh-Des Moines Steel Co., 183 F.2d 467, 472 (C.A. 3d, 1950); Myers v. San Pedro, L.A. \& S.L.R. Co., 39 Utah 198, 104 Pac. 736 (1909); see cases collected in MIcCormick, op. cit. supra note 31, at 518 n. 8.

${ }^{33}$ In Schner v. Simpson, 286 App.Div. 716, 146 N.Y.S.2d 369 (1st Dep't, 1955), defendant was sued for negligence of his employee in bumping into the plaintiff in front of defendant's store. Plaintiff sought to introduce the employee's statement that "I am sorry I knocked you down, but I think you will be able to get up." The evidence was excluded on the ground that the employee had no authority to speak in this situation. Had there been such authority, it might have been accompanied by instructions to be polite to the public, even to the point of erroneously admitting fault-instructions which the defendant could have used to explain away the harmful implications of the statement.

${ }^{34}$ See Jefferson, op. cit. supra note 22, at $7 . \quad{ }^{35}$ See note 22 supra.

${ }^{36}$ But cf. Steffen, The Employer's "Indemnity" Action, supra, at 465.
} 
against all members of the conspiracy. ${ }^{37}$ As a foundation for admissibility of these declarations against any defendant, ${ }^{38}$ the proponent must offer independent evidence of the existence of the conspiracy charged and the knowing participation of the defendant and the declarant..$^{39}$

In most jurisdictions, if the judge finds the independent evidence sufficient to take the case on the merits to the jury, he need make no independent finding as to the truth of this evidence. The declarations are admitted with an instruction that they may be considered as to any defendant only after the jury is convinced by the independent evidence that he knowingly participated in the conspiracy - that he is guilty anyway. ${ }^{40}$ Thus, under the majority rule, if the declarations have any impact at all on the jury's finding of guilt, there cannot, as a practical matter, be an independent finding by either judge or jury as to the facts theoretically necessary to render the declarations competent. Only under the so-called "orthodox" rule of judge-jury allocation-the judge making a finding on issues of competence ${ }^{41}$ - can declarations in furtherance properly be said to qualify as vicarious admissions.

These declarations are said to be vicarious admissions on the ground that joining or participating in a conspiracy constitutes "ratification" of past declarations in furtherance and "authorization" of those still to be made.42 In order to discuss the applicability of the various justifications for vicarious

${ }^{37}$ See notes 4 and 5 supra.

${ }^{38}$ The trial court generally has the discretion to admit co-conspirators' declarations subject to later independent proof of the prima facie case against the defendants. See Michael and Wechsler, Criminal Law and Its Administration 673-77 (1940).

${ }^{39}$ In order to render co-conspirators' declarations admissible, there must be a prima facie case of both the existence of the conspiracy and the connection of the defendent to it. Thomas v. United States, 57 F.2d 1039, 1041-42 (C.A. 10th, 1932); Stager v. United States, 233 Fed. 510, 513 (C.A. 2d, 1916). The distinction is illustrated by Tomplain v. United States, 42 F.2d 202, 203 (C.A. 5th, 1930): "The record shows positively that the Isabel, loaded with liquor, docked at Harry Bourg's landing. . . . A number of men and several automobiles were there, and a quantity of liquor was unloaded. The vessel, five trucks, and some of the men were captured.... It may be conceded that the evidence connecting the four appellants with the transaction was not as strong as it might have been and was disputed. However... we cannot say ... there was no evidence at all. ... The conspiracy was conclusively established, and but slight evidence connecting the defendants was necessary." Accord: McDonald v. United States, 89 F.2d 128 (C.A. 8th, 1937). See generally The Conspiracy Dilemma: Prosecution of Group Crime or Protection of Individual Defendants, 62 Harv. L. Rev. 276, 279-80 (1948). While these cases involved the sufficiency of evidence for purposes of a directed verdict, it appears that the standard for the prima facie case is similar. See United States v. Aluminum Co. of America, 1 F.R.D. 1, 3-4 (S.D.N.Y., 1939).

${ }^{40}$ See Maguire and Epstein, Preliminary Questions of Fact in Determining the Admissibility of Evidence, 40 Harv. L. Rev. 392, 415-18, 418 n. 78 (1927). But see Dennis v. United States, 183 F.2d 201, 230-31 (C.A. 2d, 1950) (L. Hand, J.).

${ }^{41}$ See Maguire and Epstein, op. cit. supra note 40, at 392.

${ }^{42}$ Van Riper v. United States, 13 F.2d 961,967 (C.A. 2d, 1926) (L. Hand, J.). See United States v. United Shoe Machinery Corp. 89 F.Supp. 349, 351-54 (D. Mass., 1950) (Wyzanski, J.); 4 Wigmore, Evidence $\$ 1079$ (3d ed., 1940). 
admissions to co-conspirators' declarations, it is necessary first to consider the relevance of these declarations to the issues in a conspiracy case.

Most of the cases seem to involve declarations with a dual aspect: an explicit assertion that a particular defendant is involved in the conspiracy, and an implication from the apparent furtherance-quality of the statement that a conspiracy existed. ${ }^{43}$ For example, in a prosecution of Goodman for conspiring with Richards to murder, after some evidence has been introduced tending to prove the charge, the prosecution can introduce testimony of a store clerk that Richards said to him "Goodman sent me to get the pistol." This statement both asserts Goodman's participation and reinforces the inference that the conspiracy to murder existed. ${ }^{44}$ The latter inference is the same as that arising from any overt act in furtherance of a conspiracy, ${ }^{45}$ and has not been considered hearsay by the courts. ${ }^{46}$ However, the chain of inference involves all the customary hearsay dangers: from the act in furtherance one infers an intent to further, which is inferred to have resulted from the conspirators' having agreed to achieve the illegal ends presently furthered. ${ }^{47}$ If this chain of inference is not considered hearsay, and declarations in furtherance were introduced only as overt acts evidencing the existence of the conspiracy, then the prima facie case of any particular defendant's participation would be a requirement of relevance: overt acts tending to establish the existence of the charged conspiracy are irrelevant as to persons not shown to

13 See Nye Nissen Co. v. United States, 168 F.2d 846, 852 (C.A. 9th,1948), aff'd 336 U.S. 613 (1949): "The existence of a conspiracy may be inferred from the acts of persons done in pursuance of an apparent criminal purpose." Cf. Maguire and Epstein, supra note 40, at 406-7: "Suppose that Smith and Jones are indicted for conspiracy to defraud by selling imitation jewelry as genuine. If the prosecution shows that on Monday Smith was absolutely destitute of funds and on Tuesday was hawking about town an assortment of paste jewelry, it is a fair inference that somebody has joined him in a conspiracy to defraud.... [I]f part of Smith's selling talk was the assertion that the well-known jeweler Jones had intrusted him with these beautiful diamonds for sale ... the hearsay rule would be drawn into issue."

"Other examples of conspirators' declarations with a similar dual aspect appear in United States v. Gooding, 12 Wheat. (U.S.) 460, 466 (1827); United States v. Renda, 56 F.2d 601, 602 (C.A. 2d, 1932); Pope v. United States, 289 Fed. 312, 315 (C.A. 3d, 1923); Stager v. United States, 233 Fed. 510,513 (C.A. 2d, 1916).

${ }^{15}$ See note 39 supra. As overt acts, declarations in furtherance might also come in as part of the crime. There is some dispute as to whether the overt act is simply a minimum evidential requirement for establishment of the unlawful agreement or is an element of the crime itself. The point has practical consequences in regard to the running of the statute of limitations, the Sixth Amendment requirement of trial in the state or district of the crime, and the propriety of proof of overt acts not alleged in the indictment. See Hyde v. United States, 225 U.S. 347, 359, 388 (1912); Criminal Conspiracy: Bearing of Overt Acts on the Nature of the Crime, 37 Harv. L. Rev. 1121 (1924).

${ }^{16}$ E.g., Pearlman v. United States, 20 F.2d 113, 114 (C.A. 9th, 1927); Pattis v. United States, 17 F.2d 562 (C.A. 9th, 1927).

17 See Stack v. United States, 27 F. 2d 16, 17 (C.A. 9th, 1928). The question of conduct as hearsay has been the subject of much scholarly debate. Authorities are collected in McCormick, Evidence 478 n. 30 (1954). 
have been involved. Under this view, reception of the declarations would merely require the presence of some other evidence showing the defendant's participation, and not an independent preliminary finding on that issue. ${ }^{48}$

However, declarations in furtherance implicating particular defendants are invariably introduced for their assertive value against implicated defendants who have been independently connected to the conspiracy. Thus the applicability of vicarious admissions doctrine as a justification for reception of these declarations is drawn into question.

The vicarious criminal responsibility of co-conspirators for acts in furtherance, ${ }^{49}$ and their vicarious evidential responsibility for declarations in

${ }^{48}$ See Maguire and Epstein, op. cit. supra note 40, at 406-7. It might be argued that the "overt act" relevance of declarations in furtherance is a sufficient peg on which to hang their admissibility even if they also explicitly implicate a co-defendant. However, the impact of the explicit assertion would usually be greater, in the case against the implicated codefendant, than the "overt act" relevance. Reliance on limiting instructions in this situation would seem so futile as to be unjustifiable, despite the law's generally favorable attitude toward multiple admissibility. Compare Delli Paoli v. United States, 352 U.S. 232 (1957), noted in 24 U. of Chi. L. Rev. 710 (1957) (post-conspiracy admission implicating a co-defendant held admissible against admitter in joint prosecution, court rejecting argument that instructions limiting use of evidence to case against admitter are futile), with United States v. Gordon, 253 F. 2d 177, 183 (C.A. 7th, 1958) (opposite result reached, Delli Paoli distinguished on ground that in instant case the admission played a minor role against the admitter while having a great prejudicial impact against his co-defendants). The Delli Paoli case might also be distinguished on the ground that admission of a hearsay declaration in furtherance for its "overt-act" relevance would demand a greater degree of subtlety from the jury; it would be necessary to separate the explicit and overt-act impact of the evidence on the case against the same defendant. The situation would be analogous to Shepard v. United States, 290 U.S. 96 (1933), where, in connection with the Government's suggestion that the deceased's declaration accusing the defendant of poisoning her could be limited to a showing of a state of mind inconsistent with the defense of suicide, Justice Cardozo made his oftcited statement that "[d]iscrimination so subtle is a feat beyond the compass of ordinary minds. The reverberating clang of those accusatory words would drown all weaker sounds. It is for ordinary minds ... that our rules of evidence are framed." Id., at 104.

${ }^{49}$ In Pinkerton v. United States, 328 U.S. 640 (1946), noted in 56 Yale L. J. 371 (1947), the Court upheld the conviction of a conspirator for various substantive offenses committed by his co-conspirator. The jury had been instructed that conviction of any menber of the conspiracy for the substantive offense was proper if the offense was in furtherance of the conspiracy. The opinion, however, stated that "[a] different case would arise if the substantive offense . . . did not fall within the scope of the unlawful project, or was merely a part of the ramifications of the plan which could not be reasonably foreseen as a necessary or natural consequence of the unlawful agreement." Pinkerton v. United States, supra, at 647-48. See Nye \& Nissen v. United States, 336 U.S. 613, 620 (1949). This limitation would not seem to be seriously restrictive as applied to declarations in furtherance. However, although the language of the Pinkerton opinion is ambiguous on this point, an additional limitation might be imposed in accordance with the analysis in Sayre, Criminal Responsibility for the Acts of Another, 43 Harv. L. Rev. 689, 716-23 (1930): if Sayre is correct in his argument that criminal responsibility for another's act may be imposed only on one who has helped to cause the act, then substantive responsibility for acts in furtherance could not be placed on a defendant who joined the conspiracy after their commission. Yet it is well settled that declarations in furtherance are admissible against a defendant who joined the conspiracy after their utterance; by joining he is said to "ratify" the prior declarations. See Van Riper v. United States, 13 F.2d 961, 967 (C.A. 2d, 1926). 
furtherance, are often said to rest on the same basis-a ratification or authorization implicit in the act of joining or participating in a conspiracy. The rationale for criminal responsibility in this situation lies in the idea that acts in furtherance are a probable and intended result of such participation. ${ }^{50}$ The idea seems to be that one who achieves criminal objectives by acting through others ought to be as responsible for what is done as if he himself committed the crime. This substantive policy seems to have some relevance to the evidence question. If ability to introduce declarations of the actor during the course of the crime significantly increases the chance of conviction, exclusion as against co-conspirators of declarations made during the course of a conspiracy would help make the more active and talkative members run the greatest chance of conviction, although all members are considered equally responsible. However, if these declarations when received against co-conspirators are less reliable or necessary than direct admissions, the co-conspirators' exception may make unjust convictions for conspiracy more probable than for individual crime. This result may be justified: the danger to society posed by conspiracy may make it worth while to incur an added danger of unjust convictions in order to achieve more effective deterrence. However, in view of the other dangers of prejudice to defendants resulting from the conspiracy charge, ${ }^{51}$ it would seem that a rule of evidence not founded on necessity or reliability should not be employed in conspiracy cases without a full consideration of its dangers.

As a guarantee of reliability for co-conspirators' declarations, ability-to-explain presents considerable difficulties. Many conspiracies involve numerous participants, some of whom have little knowledge and less control of what the others are doing and saying. ${ }^{52}$ To establish a foundation for admission of the declarations, the defendants need not be shown aware of the full scope of the conspiracy, ${ }^{53}$ nor acquainted with the declarant and his function in the plan. ${ }^{54}$ Such "peripheral" conspirators present the most likely target of a case based

${ }^{50}$ Sayre, Criminal Responsibility for the Acts of Another, 43 Harv. L. Rev. 689, 716-23 (1930). Cf. Nye \& Nissen v. United States, 336 U.S. 613 (1949); United States v. Peoni, 100 F.2d 401 (C.A. 2d, 1938) (L. Hand, J.). Sayre makes an exception to this principle for the "regulatory" crimes created by speed ordinances, pure food laws, liquor regulation, economic regulation, and the like. Sayre, supra, at 719-21.

si See note 3 supra.

52 While the classic examples of this are the political conspiracy, see United States v. Dennis, 183 F.2d 201, 230-32 (C.A. 2d, 1950), and the restraint-of-trade conspiracy, FTC v. Cement Institute, 333 U.S. 683 (1948), in other more common types of conspiracy one frequently finds numerous conspirators. See Blumenthal v. United States, 332 U.S. 539 (1947) (conspiracy to violate OPA ceiling prices); Jezewski v. United States, 13 F.2d 599 (C.A. 6th, 1926) (conspiracy to violate Prohibition-45 defendants); Marx v. United States, 86 F.2d 245 (C.A. 8th, 1936) (sale of liquor without federal revenue stamps-7 conspirators).

${ }^{53}$ United States v. Anderson, 101 F.2d 325, 332-33 (C.A. 7th, 1939).

54 Blumenthal v. United States, 332 U.S. 539 (1947); Jezewski v. United States, 13 F.2d 599 (C.A. 6th, 1926). 
primarily on co-conspirators' declarations, since the central figures in the conspiracy are likely to be caught by their own admissions. Yet conspirators on the periphery are unlikely to be able to explain what the others said. Moreover, to explain the implications of a conspirator's statement may require a defendant to admit close acquaintance with the declarant. The acquaintance may be innocent, but it raises the danger of the jury's attaching guilt by association. Thus Goodman may explain that he and Richards intended to go rabbit hunting with the pistol. But since Richards has already been shown prima facie to have been involved in the charged conspiracy, association with him appears suspect.

Admission of most declarations in furtherance might arguably be justified by their against-interest quality. In this connection it is again necessary to distinguish the dual relevance of these declarations. Richards' statement that Goodman sent him to buy a pistol tends to involve the declarant in some kind of criminal activity. ${ }^{\mathbf{5}}$ Such a statement increases the possibility of apprehension and conviction and so would presumably not be made unless the declarant had some interest in a project which would be furthered by the statement. ${ }^{56}$ On this basis, one might say that an against-interest guarantee of reliability extends to declarations introduced solely as overt acts in furtherance. However, there may well be no such guarantee as to the aspect of the declaration which implicates particular defendants. The necessity for secrecy might well lead a conspirator to use code names or to create a false impression as to the membership of the conspiracy. ${ }^{57}$ Thus use of a particular name could be prompted by a variety of reasons: Richards may have used Goodman's name without authority to get credit for his purchase.

It has been said that admission of co-conspirators' hearsay declarations is justified by necessity. The suggestion is that criminal agreements are inherently secret, that participation is possible without commission of overt acts, and consequently that there is a necessity sufficient to justify admission of hearsay of questionable reliability. ${ }^{58}$ However, the necessity argument alone does

${ }^{55}$ See text at note 44 supra.

${ }^{55}$ Of course, the against-interest quality of declarations in furtherance varies with the circumstances. Thus, it may be that anyone would relay information on where to buy illegal liquor, without raising suspicions as to his own involvement in the conspiracy. See Pope v. United States, 289 Fed. 312, 315 (C.A. 3d, 1923). The same might be said of gambling, prostitution, black market and narcotics-"commercial" conspiracies relying on public knowledge and patronage.

${ }^{57}$ See the example posed by Maguire and Epstein, supra note 43: Smith may well have used Jones's name in his selling talk to lend prestige to his merchandise or to conceal his real co-conspirator.

58 See Levie, Hearsay and Conspiracy, 52 Mich. I. Rev. 1159 (1953). Courts often invoke necessity as a reason for allowing proof of conspiracy by circumstantial evidence. See Underhill, Criminal Evidence $\$ \$ 857-59$ (5th ed., Herrick, 1957). However, in these cases the circumstantial evidence does not consist of co-conspirators' declarations identifying defendants as parties to the conspiracy. Ibid. 
not adequately explain the requirement that admission be preceded by independent evidence sufficient to raise a jury issue and coincident with the evidence on the merits: the declarations are hardly "necessary" to get the case to the jury. It might be argued that the declarations are still necessary in many cases to convince the jury. However, it would seem that if the jury places heavy reliance on this evidence, it ought to have some guarantee of reliability.

There is good reason, however, to believe that testimony of oral declarations in furtherance is likely to be extremely unreliable. Not only might the declarations be inadvertently misreported, but in an uncertain case there is pressure on the prosecution to fabricate evidence. ${ }^{59}$ This may easily be done in a conspiracy case, where testimony may be elicited from conspirators as yet untried or unsentenced, and where alleged auditors of declarations may be chosen from a wide range of participants and events, with a view to making investigation and cross-examination most difficult. ${ }^{B 0}$

The absence of a guarantee of reliability for co-conspirators' declarations, and their ease of fabrication, present a strong case for rejection of the hearsay exception. Although the hearsay rule is under attack from all quarters, its enforcement in criminal proceedings is materially more appealing than in civil litigation, ${ }^{61}$ and may even be required by a criminal defendant's constitutional right to confrontation. ${ }^{62}$ Criticism of the co-conspirators' exception is in part a reflection of criticism directed at the conspiracy charge itself. Thus the wide range of events frequently covered by the charge, ${ }^{63}$ with which the defendant has often had little connection, both weakens his general ability to explain evidence ${ }^{64}$ and enhances the ease of fabrication by the prosecution. To the extent that the case against the co-conspirators' exception rests on such arguments,

${ }^{59} \mathrm{McC}$ Cormick argues that one reason for the hearsay rule is that the report in court of an oral declaration is likely to be unreliable. McCormick, Evidence 458 (1954).

${ }^{60}$ See note 52 supra. A prosecutor bent on fabrication might also manufacture direct admissions. Such evidence might have more impact than co-conspirators' declarations. But fabrication of a direct admission is more dangerous, since the admitter can more effectively deny having made the statement.

${ }^{61}$ See United States v. Delli Paoli, 229 F.2d 319, 323, aff'd 352 U.S. 232 (1957) (Frank J., dissenting): "Even among these (like Judge Hand and me) who would like to have legislation enacted wiping out or drastically modifying the hearsay rule in civil action, there are few who do not agree that, for the most part, it should be retained in criminal actions because it importantly serves the interests of justice to those accused of crime." But cf. Model Code of Evidence, Rules 1 (1), 2, 503.

${ }^{62}$ See 5 Wigmore, Evidence $\$ 1397$ (3d ed., 1940), concluding that the constitutional right of confrontation merely requires that testimony which the hearsay rule requires to be given in court be subject to cross-examination. See Stein v. New York, 346 U.S. 156, 194-96 (1953), discussed in Meltzer, Involuntary Confessions: The Allocation of Responsibility between Judge and Jury, 21 U. of Chi. L. Rev. 317, 318 n. 10 (1954).

${ }^{63}$ See note 52 supra.

64 See O'Dougherty, Prosecution and Defense under Conspiracy Indictments, 9 Brooklyn L. Rev. 263, 286 (1940). 
it must ultimately depend on an assessment of the desirability of the charge. The exception does present objectionable features not common to other evidence in conspiracy cases. For example, the fact that the foundation of admissibility consists of evidence sufficient to convict, weakens the "necessity" rationale and, in combination with failure to follow the orthodox rule of judgejury allocation, results in a complete absence of any finding on the issue of competence. However, since conspirators' hearsay declarations have traditionally played such an important role in conspiracy prosecutions, a change in the rule of evidence is not likely to occur without a complete re-assessment of the desirability of the conspiracy offense as a tool of prosecution. 